
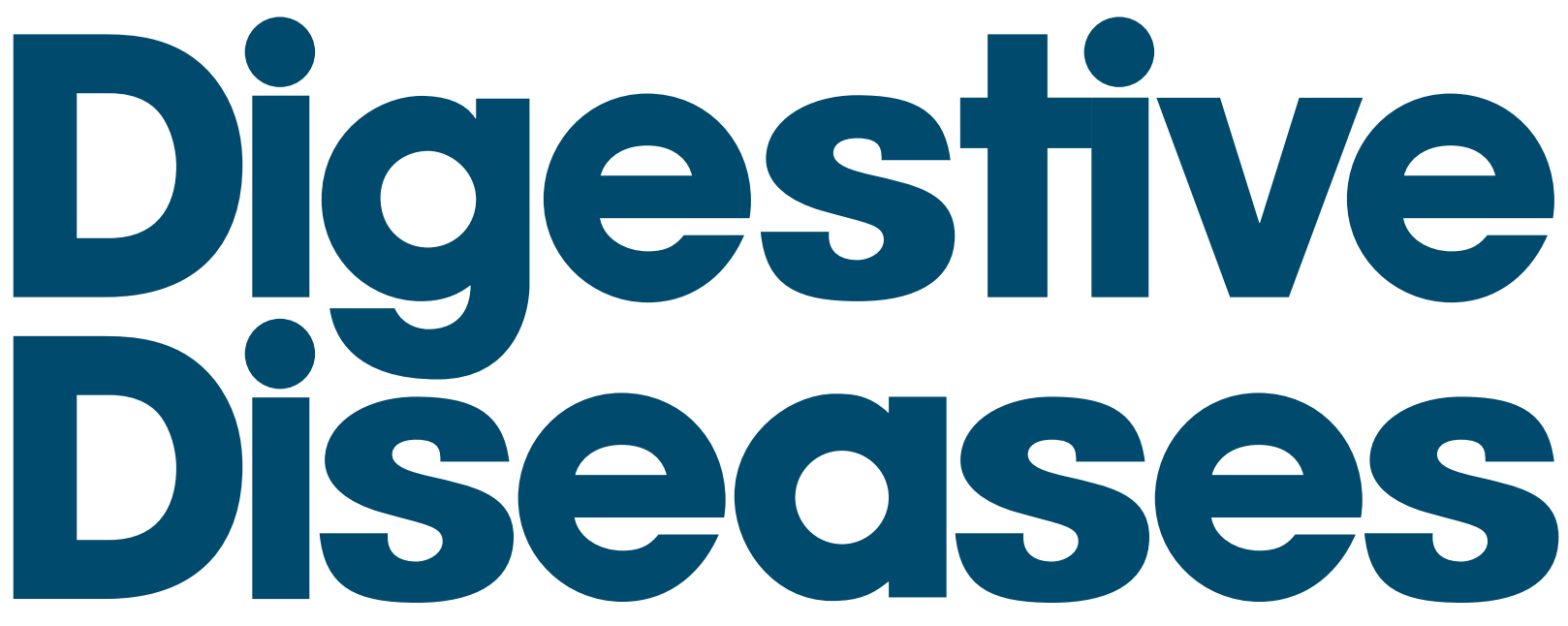

Official Journal of
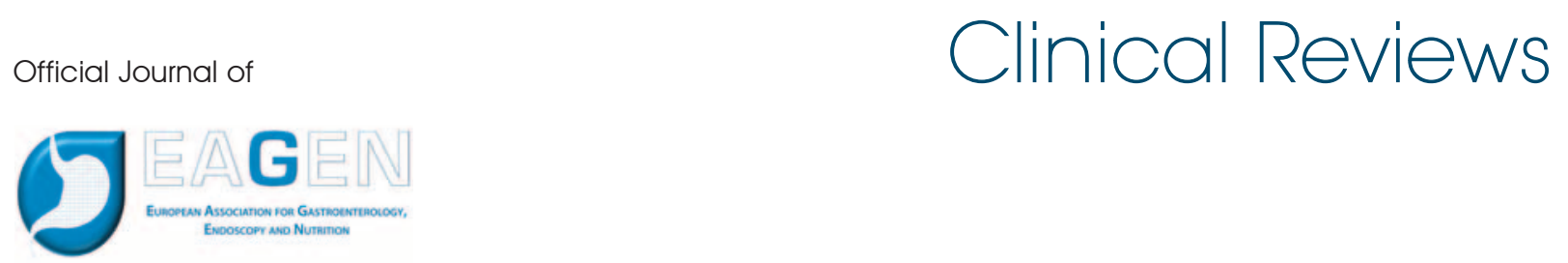

\title{
Inflammation and Cancer
}

\author{
Editors \\ G. Tiegs, Hamburg \\ A.W. Lohse, Hamburg \\ R. Thimme \\ C. Trautwein, Aachen
}




\section{New Journal}

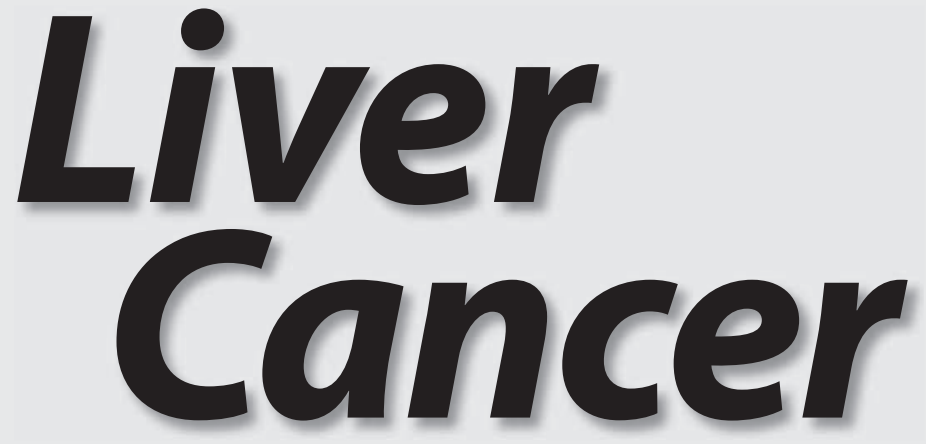

Clinical Reviews

Editior

M. Kudo, Osaka

Associate Editors

P.-J. Chen, Taipei

A.-L. Cheng, Taipei

K.-H. Han, Seoul

N. Izumi, Tokyo

N. Kokudo, Tokyo

\section{J.M. Lee, Seoul}

R. Lencioni, Pisa

J. Ricke, Magdeburg

L.R. Roberts, Rochester,

Minn.

M. Sakamoto, Tokyo

A. Villanueva, Barcelona

S.-L. Ye, Shanghai

A.X. Zhu, Boston, Mass.
Affiliated with the Asia-Pacific Primary Liver Cancer Expert Meeting (APPLE)

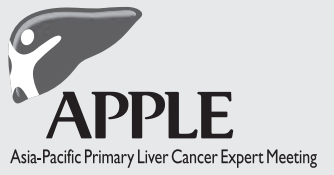

Liver Cancer
More information at

\section{www.karger.com/lic}

- Pay-per-View and Subscriber Access to Full Text

- Full Table of Contents

- Full Editorial Board

- Free Abstracts and Selected Articles

- Online Sample Issue

- Submission/Guidelines for Authors

- Subscription Details

- Free Alert Service

- Online Library Recommendation

\section{Contents of the first issue}

- Welcome to the First Issue of Liver Cancer: Kudo, M. (Osaka)

- Epidemiology and Surveillance of Hepatocellular Carcinoma: Kim, D.Y.;

Han, K. (Seoul)

- Clinical Application of Fluorescence Imaging of Liver Cancer Using Indocyanine Green: Kokudo, N.; Ishizawa, T. (Tokyo)

- Recent Advances in CT and MR Imaging for Evaluation of Hepatocellular Carcinoma: Lee, J.; Yoon, J.H.; Joo, I.; Woo, H.S. (Seoul)

- Chemoembolization in Patients with Hepatocellular Carcinoma: Lencioni, R. (Pisa)

- Noninvasive Diagnosis of Hepatocellular Carcinoma in Cirrhotic Liver: Current Guidelines and Future Prospects for Radiological Imaging: Ricke, J.;

Seidensticker, M.; Mohnike, K. (Magdeburg)

\section{Submission of papers}

The editor cordially invites you to submit your clinical review paper to Liver Cancer. Manuscripts written in English should be submitted to the Editorial Assistant, Ms. Tanja Sebuk: t.sebuk@karger.ch
Liver cancer has a very high prevalence among cancers in general and is one of the most common causes of death worldwide. Based on these facts, the journal Liver Cancer serves the growing need to better understand the causes, mechanisms and therapy of the malignancy. It provides the international community of researchers and clinicians with a platform for their research results, focusing on molecular carcinogenesis, prevention, surveillance, diagnosis and treatment, including molecular targeted therapy, of the disease. Liver Cancer publishes clinical and translational research related to the field of liver cancer in both humans and experimental models in the form of review articles.

Liver Cancer

2013: Volume 2

4 issues per volume

Language: English

ISSN 2235-1795

ISSN online 1664-5553 


\section{Official Journal of}

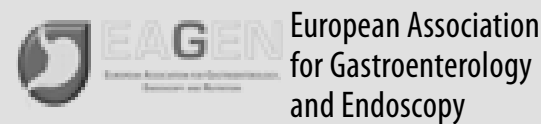

\section{EAGEN Society Representatives}

L. Lundell, Stockholm

J. Regula, Warsaw

J. Tack, Leuven

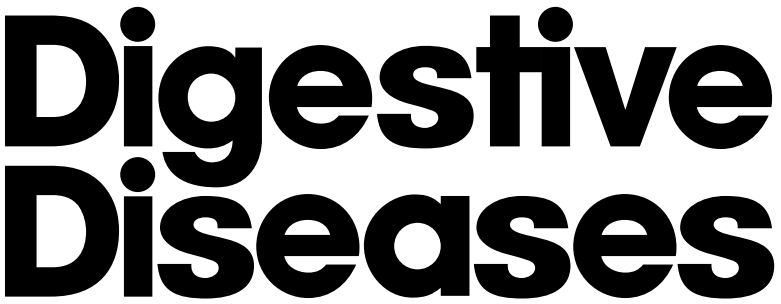

Clinical Reviews

Formerly 'Survey of Digestive Diseases'

Founded in 1983 by T.S.N. Chen and R.K. Zetterman

Former Editor: S.R. Achem (1993-2000)

\section{Editor-in-Chief}

P. Malfertheiner, Magdeburg

\section{Assistant Editor}

M. Ebert, München

\section{Editorial Board Members}

Europe

F. Bazzoli, Bologna

M.W. Büchler, Heidelberg

P. Dítě, Brno

J.E. Domínguez-Muñoz,

Santiago de Compostela

P. Ferenci, Vienna

J.-P. Galmiche, Nantes

G. Gasbarrini, Rome

S.D. Ladas, Athens

L. Lundell, Stockholm

K.E.L. McColl, Strathblane

P. Michetti, Lausanne

C. O'Morain, Dublin

G. Rogler, Zürich

Z. Tulassay, Budapest

G.N.J. Tytgat, Amsterdam
Asia Pacific

M. Asaka, Sapporo

K.-L. Goh, Kuala Lumpur

K.M. Fock, Singapore

J.D. Sollano, Manila

K. Sugano, Shimotsuke

J.Y. Sung, Hong Kong

N.J. Talley, Callaghan

Africa

S.M.A. Fattah Sherif, Cairo

J.A. Louw, Cape Town

North America

S.R. Achem, Jacksonville, Fla.

R. Fass, Tucson, Ariz.

M. Korc, Irvine, Calif.

N. Vakil, Milwaukee, Wisc.

\section{South America}

M. Lizarzabal, Maracaibo

G.B. Salis, Buenos Aires
Printed in Switzerland on acid-free and non-aging paper (ISO 9706) by

Reinhardt Druck, Basel
Appears bimonthly: 1 volume per year (6 issues) 


\section{Digestive \\ Diseases}

ISSN Print Edition: 0257-2753

ISSN Online Edition: 1421-9875

Journal Homepage: www.karger.com/ddi

Publication Data: 'Digestive Diseases' is published 6 times a year. Volume 30 with 6 issues appears in 2012 .

Copyright: ( 2012 S. Karger AG, Basel (Switzerland). All rights reserved. No part of this publication may be translated into other languages, reproduced or utilized in any form or by any means, electronic or mechanical, including photocopying, recording, microcopying, or by any information storage and retrieval system, without permission in writing from the publisher or, in the case of photocopying, direct payment of a specified fee to the Copyright Clearance Center.

Disclaimer: The statements, opinions and data contained in this publication are solely those of the individual authors and contributors and not of the publisher and the editor(s). The appearance of advertisements in the journal is not a warranty, endorsement, or approval of the products or services advertised or of their effectiveness, quality or safety. The publisher and the editor(s) disclaim responsibility for any injury to persons or property resulting from any ideas, methods, instructions or products referred to in the content or advertisements.
Subscription Rates: Subscriptions run for a full calendar year. Prices are given per year. Personal subscription:

Print or Online

CHF 320.-

EUR 256.-

USD 311.00

Print+Online combined CHF 368.-

EUR 294.-

USD 358.00

postage and handling (added to print and print+online)

CHF 40.80 Europe, CHF 60.- Overseas

EUR 31.20

USD 56.40

Institutional subscription

Print or Online

Print+Online combined

CHF 2295.

EUR 1836.-

CHF 2525.-

postage and handling (added to print and print+online)

CHF 51.- Europe, CHF 75.- Overseas

EUR 39.-

USD 70.50

Airmail surcharge: CHF 51.- / USD 48.00

Discount subscription prices:

Please enquire about reduced rates for residents.
Back Volumes and Single Issues: Information on availability and prices of single print issues and print or electronic back volumes can be obtained from Customer Service at service@karger.ch.

Bibliographic Indices: This journal is regularly listed in bibliographic services, including Current Contents ${ }^{\circledR}$ and PubMed/MEDLINE.

Photocopying: This journal has been registered with the Copyright Clearance Center (CCC), as indicated by the code appearing on the first page of each article. For readers in the US, this code signals consent for copying of articles for personal or internal use, or for the personal or internal use of specific clients, provided that the stated fee is paid per copy directly to

Copyright Clearance Center Inc.

222 Rosewood Drive

Danvers, MA 01923 (USA)

A copy of the first page of the article must accompany payment. Consent does not extend to copying for general distribution, for promotion, for creating new works, or for resale. In these cases, specific written permission must be obtained from the copyright owner,

S. Karger AG, P.O. Box

CH-4009 Basel (Switzerland).
Subscription Orders:

Orders can be placed at agencies,

bookstores, directly with the Publisher

\section{S. Karger AG}

Medical and Scientific Publishers

P.O. Box

CH-4009 Basel

Switzerland

(for courier services only:

Allschwilerstrasse 10

CH-4055 Basel)

t: +41613061111

f: +41613061234

e: karger@karger.ch

w: www.karger.com or further Karger offices

or representatives:

Germany

S. Karger GmbH

Postfach

79095 Freiburg

Deutschland

(Hausadresse: Wilhelmstrasse 20A,

79098 Freiburg)

t: +49761452070

f: +497614520714

e: information@karger.de

w: www.karger.de

Japan

Karger Japan, Inc.

Shiba Daimon Asahi Bldg. 2F

1-2-23 Shiba Daimon

Minato-ku

Tokyo 105-0012

Japan

t: +81364356242

f: +81364356244

e: publisher@karger.jp

w: www.karger.jp

Change of Address:

Both old and new address should be sent

to the subscription source.

USA

S. Karger Publishers, Inc.

26 West Avon Road

P.O. Box 529

Unionville, CT 06085

USA

Toll free: +18008285479

t: +18606757834

f: +18606757302

e: karger@snet.net

France

Librairie Médi-Sciences Sar

36, bd de Latour-Maubourg

75007 Paris

France

$\mathrm{t}:+33(0) 145514258$

f: $+33(0) 145560780$

f: +33(0) 145560780

e: librairie@medi-sciences.

Gulf Council Countries, Iran,

Middle East, North Africa, Turkey

Trans Middle East International

Distribution Co. Ltd. (KaSha)

168 B, King Abdullah the 2nd Street

Daboog Building 2nd Floor

Daboog Area

P.O. Box 2376

Amman 11953

Jordan

t: +96265153467

f: +96265411336

e: info@kasha.cc

w: www.KaShaonline.com
South East Asia, China and Taiwan

Karger Regional Office (Malaysia)

CEO Suite Kuala Lumpur

Quill 7, 27th Floor

Jalan Stesen Sentral 5

KL Sentral

Kuala Lumpur 50470

Malaysia

t: +60327766803

f: +60327766999

e: service@karger.cn; r.chew@karger.cn

Karger China

10th Floor, Twin Towers (East)

B12 Jianguomenwai Avenue

Beijing 100022

China

t: +861051235033

f: +861051235122

e: service@karger.cn; r.chew@karger.cn

w: www.karger.cn

India, Bangladesh, Sri Lanka

Medscience India

Plot No. 17, Yusuf Sarai Market

B.L. Glass Building, 2nd Floor

Sri Aurobindo Marg

New Delhi 110016

India

t: +911146029633

f: +911146029634

c: +919891052128

e: medsci.india@gmail.com

\section{KARGER}

Fax +41 613061234

E-Mail karger@karger.ch

www.karger.com
(C) 2012 S. Karger AG, Basel

The Journal Home Page is available at:

www.karger.com/ddi 


\section{Contents}

See the journal website for contents

KARGER Basel $\bullet$ Freiburg $\cdot$ Paris $\bullet$ London $\bullet$ New York $\cdot$ New Delhi $•$ Bangkok Beijing $\cdot$ Tokyo $\cdot$ Kuala Lumpur $\cdot$ Singapore $\bullet$ Sydney 


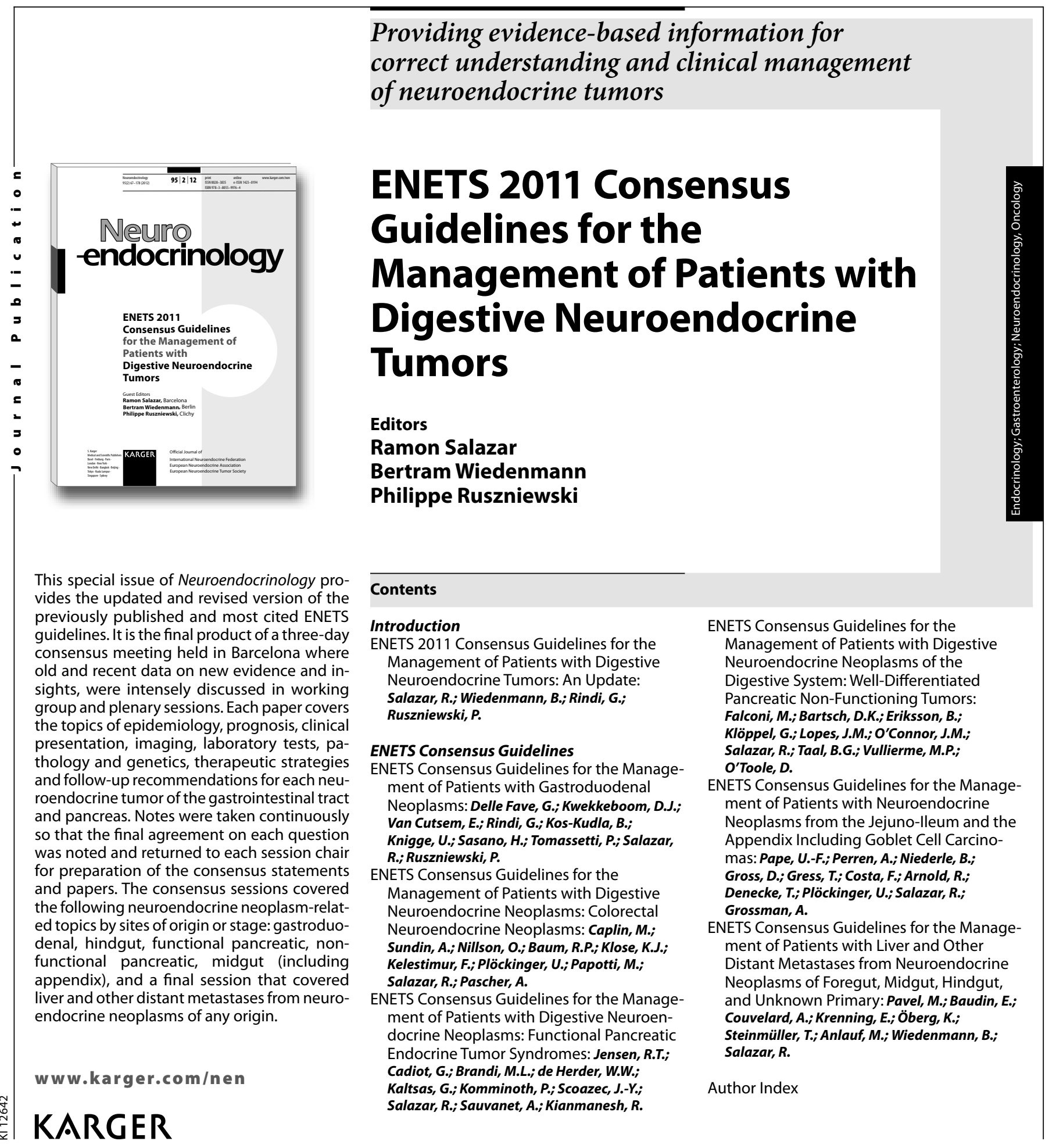

ENETS 2011 Consensus Guidelines for the Management of Patients with Digestive Neuroendocrine Tumor with Digestive Neuroendocrine Tumor
Editors: Salazar, R. (Barcelona); Wiedenmann, B. Editors: Salazar, R. (Barcelona);
(Berlin); Ruszniewski, P. (Clichy) 112 p., 7 fig., 2 in color, 9 tab., hard cover, 2012 CHF 39.- / EUR 33.- / USD 46.00 Prices subject to change

EUR price for Germany, USD price for USA only ISBN 978-3-8055-9976-4 / e-ISBN 978-3-8055-9977-1 =

Special Topic Issue:

Neuroendocrinology

Vol. 95, No. 2 (2012)

Included in subscription

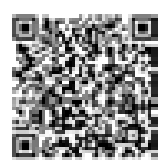

$\rightarrow$ Please send: ___ copy/ies

Postage and handling free with prepayment

$\boldsymbol{\varepsilon}$

Payment:

Please charge to my credit card

- $\square$ American Express $\square$ Diners

$\square$ MasterCard

Card No:

Exp. date:

- $\mathrm{CVV} / \mathrm{CVC}$

( 3 digits in the signature field on the back of Visa and MasterCard)

$\square$ Check enclosed $\quad \square$ Please bill me

Orders may be placed with any bookshop, subscription agency, directly with the publisher or through a Karger distributor.
Fax: +41613061234

S. Karger AG, P.O. Box, CH-4009 Basel (Switzerland) E-Mail orders@karger.ch, www.karger.com

Name/Address:

Date: 


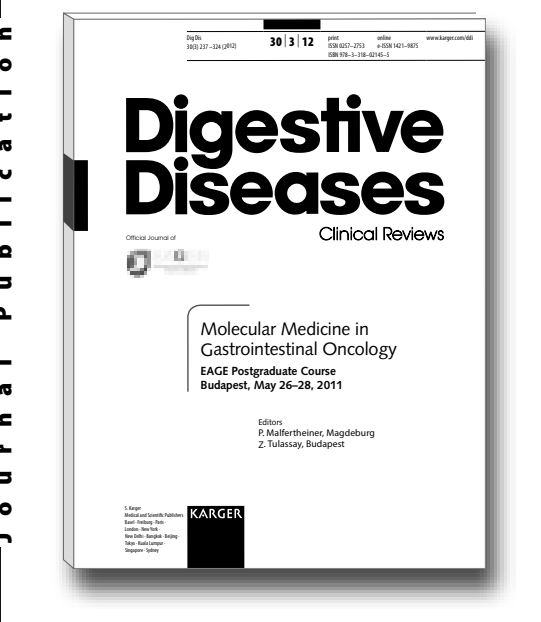

\section{Contents}

Preface: Tulassay, $\boldsymbol{Z}$.

Molecular Hepatic Carcinogenesis: Impact of Inflammation: Szabo, G.; Lippai, D.

The Role of Inflammation and Proteinases in Tumor Progression: Herszényi, L.; Lakatos, G.; Hritz, I.; Varga, M.Z.; Cierny, G.; Tulassay, Z.

Macro-Role of MicroRNA in Gastric Cancer: Link, A.; Kupcinskas, J.; Wex, T.;

Malfertheiner, $P$.

Markers for Gastric Cancer Premalignant Lesions: Where Do We Go? Leja, M.; Wex, T.; Malfertheiner, $P$.

The Role of Chronic Inflammation: Chronic Pancreatitis as a Risk Factor of Pancreatic Cancer: Dítě, P.; Hermanová, M.; Trna, J.; Novotný, l.; Rưžička, M.; Liberda, M.; Bártková, $A$.

\title{
Molecular Medicine in Gastrointestinal Oncology \\ EAGE Postgraduate Course, Budapest, May 2011
}

\author{
Editors \\ P. Malfertheiner \\ Z. Tulassay
}

Molecular Targeted Therapy in Hepatocellular Carcinoma: Present Achievements and

Future Challenges: Giacomin, A.; Sergio, A.; Vanin, V.; Gazzola, A.; Cazzagon, N.; Farinati, F.

The Impact of Matrix Metalloproteinases and Their Tissue Inhibitors in Inflammatory Bowel Diseases: Lakatos, G.; Hritz, l.; Varga, M.Z.; Juhász, M.; Miheller, P.; Cierny, G.; Tulassay, Z.; Herszényi, L.

Novel Prognostic Biomarkers in Colorectal Cancer: Malesci, A.; Laghi, L.

Microsatellite Instability and Therapeutic Consequences in Colorectal Cancer: Laghi, L.; Malesci, A.

Role of DNA Methylation in Colorectal Carcinogenesis: Patai, Á.V.; Molnár, B.; Kalmár, A.; Schöller, A.; Tóth, K.; Tulassay, Z.
Isolated Colorectal Cancer Screening or Integrated Cancer Prevention?

A Provocative Suggestion! Stockbrugger, $\boldsymbol{R}$.

New European Initiatives in Colorectal Cancer Screening: Budapest Declaration. Official Appeal during the Hungarian Presidency of the Council of the European Union under the Auspices of the United European Gastroenterology Federation, the European Association for Gastroenterology and Endoscopy and the Hungarian Society of Gastroenterology: Wittmann, T.; Stockbrugger, R.; Herszényi, L.; Jonkers, D.; Molnár, B.; Saurin, J.-C.; Regula, J.; Malesci, A.; Laghi, L.; Pintér, T.; Teleky, B.; Dítě, P.; Tulassay, $Z$.

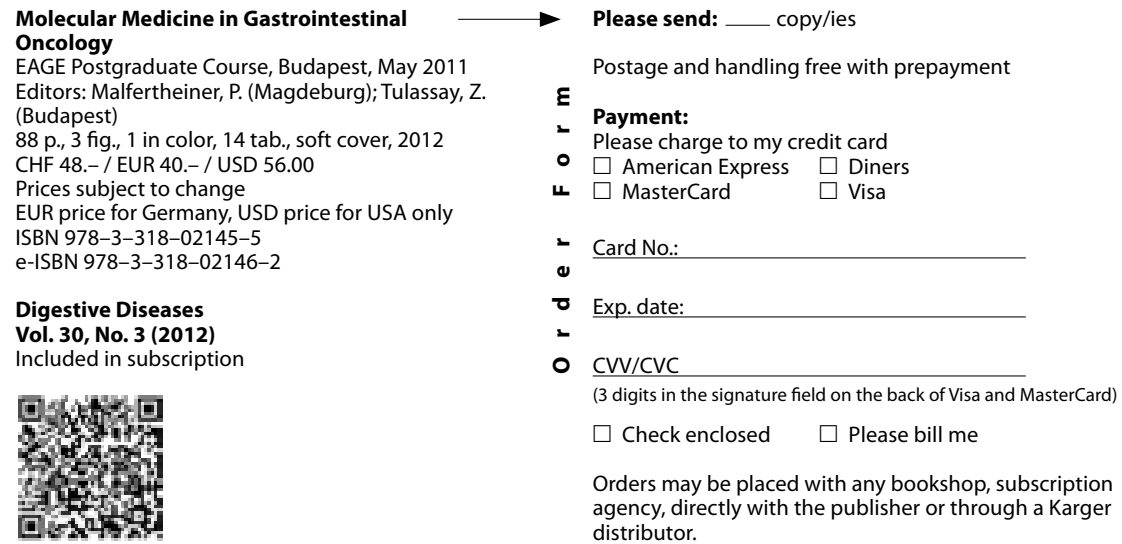

\section{Molecular Medicine in Gastrointestinal} Oncology

EAGE Postgraduate Course, Budapest, May 2011 Editors: Malfertheiner, P. (Magdeburg); Tulassay, Z. (Budapest)

88 p., 3 fig., 1 in color, 14 tab., soft cover, 2012 CHF 48.- / EUR 40.- / USD 56.00

Prices subject to change

EUR price for Germany, USD price for USA only

ISBN 978-3-318-02145-5

e-ISBN 978-3-318-02146-2

Digestive Diseases

Vol. 30, No. 3 (2012)

Included in subscription

$\rightarrow$ Please send: __ copy/ies

Postage and handling free with prepayment

E Payment:

- Please charge to my credit card

- $\square$ American Express $\square$ Diners

ᄂ $\square$ MasterCard $\square$ Visa

- Card No.:

$\boldsymbol{v}$

$\nabla$

-

- CVV/CVC

( 3 digits in the signature field on the back of Visa and MasterCard)

$\square$ Check enclosed $\quad \square$ Please bill me

Orders may be placed with any bookshop, subscription agency, directly with the publisher or through a Karger distributor.

Fax: +41613061234

S. Karger AG, P.O. Box, CH-4009 Basel (Switzerland)

E-Mail orders@karger.ch, www.karger.com

Name/Address: 


\section{Comprehensive coverage of selected topics}

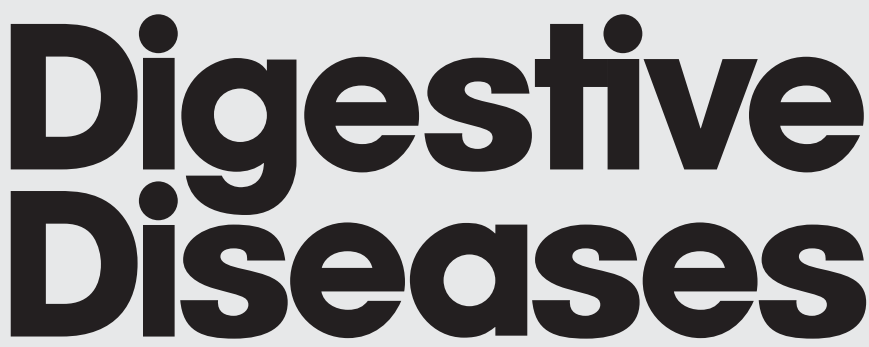

Clinical Reviews

Editor-in-Chief

P. Malfertheiner,

Magdeburg
Official Journal of

European Association for

Gastroenterology, Endoscopy and Nutrition

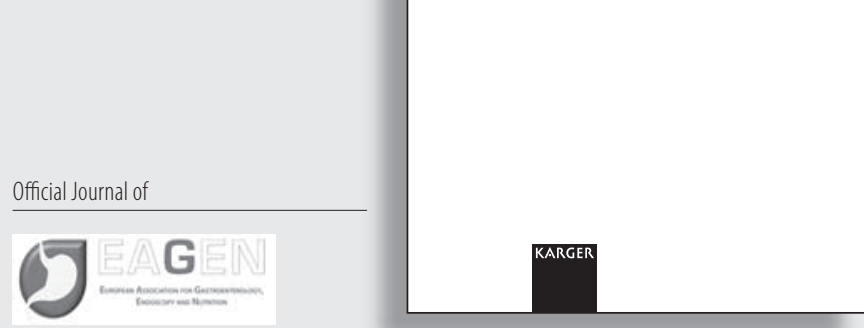

\section{Digestive \\ Diseases}

(⿹丁口
More information at

\section{www.karger.com/ddi}

- Pay-per-View and Subscriber Access to Full Text

- Full Table of Contents

- Full Editorial Board

- Free Abstracts and Selected Articles

- Online Sample Issue

- Submission/Guidelines for Authors

- Subscription Details

- Free Alert Service

- Online Library Recommendation

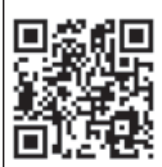

Digestive Diseases

2013: Volume 31

6 issues per volume

Language: English

ISSN 0257-2753 (print)

ISSN 1421-9875 (online)

\section{Recent Topics}

- Revisiting IBD Management: Dogmas to Be Challenged ISBN 978-3-318-02185-1

- Molecular Medicine in Gastrointestinal Oncology ISBN 978-3-318-02145-5

- Metabolic and Autoimmune Diseases of the Digestive System ISBN 978-3-8055-9998-6

- Diverticular Disease: A Fresh Approach to a Neglected Disease ISBN 978-3-8055-9978-8

- Gut Microbiota: The Forgotten Organ ISBN 978-3-8055-9890-3

- Acid Inhibition and Peptic Ulcer - 100 Years of Carl Schwarz's Dictum:

No Acid - No Ulcer ISBN 978-3-8055-9888-0

- Liver and Immunology ISBN 978-3-8055-9845-3

- Molecular Targeted Therapy for Hepatocellular Carcinoma: Bench to Bedside ISBN 978-3-8055-9761-6

- Environment and Lifestyle - Effects on Disorders of the Digestive Tract ISBN 978-3-8055-9714-2

- Bile Acids as Metabolic Integrators and Therapeutics ISBN 978-3-8055-9727-2

- Liver and Pancreatic Diseases: Consequences of Chronic Alcoholic Consumption ISBN 978-3-8055-9732-6

- Endoscopy Live Berlin 2011 - Intestinal Disease Meeting ISBN 978-3-8055-9874-3

- From Chronic Inflammation to Cancer ISBN 978-3-8055-9611-4

- The Keys to IBD 2010: Treatment, Diagnosis and Pathophysiology

ISBN 978-3-8055-9589-6

- Pancreatic Diseases ISBN 978-3-8055-9523-0

- Immunology and Liver Disease / Liver and Metabolic Syndrome

ISBN 978-3-8055-9425-7

- Inflammation in the Intestinal Tract: Pathogenesis and Treatment

ISBN 978-3-8055-9282-6
Each issue of this journal is dedicated to a special topic of current interest, covering both clinical and basic science topics in gastrointestinal function and disorders. The contents of each issue are comprehensive and reflect the state of the art, featuring editorials, reviews, mini reviews and original papers. These individual contributions encompass a variety of disciplines including all fields of gastroenterology. Digestive Diseases bridges the communication gap between advances made in the academic setting and their application in patient care. The journal is a valuable service for clinicians, specialists and physicians-in-training. 


\section{Digestive \\ Diseases}

Clinical Reviews

\section{Inflammation and Cancer}

Editors

G. Tiegs, Hamburg

A.W. Lohse, Hamburg

R. Thimme

C. Trautwein, Aachen 